\title{
The Constitutional Vulnerabilities of Kansas's Income Tax Reforms
}

\section{INTRODUCTION}

On January 1, 2013, Senate Substitute for House Bill 2117 (HB 2117) went into full effect and instituted an unprecedented approach to state income taxation. ${ }^{1}$ HB 2117 changed who is subject to income taxes in Kansas and entirely exempts many business owners while their employees continue to pay. ${ }^{2}$ While this bill altered Kansas income tax law in several "revolutionary" ways, ${ }^{3}$ this Comment specifically addresses several constitutional vulnerabilities created by these "revolutionary" features.

Part II of this Comment first examines the practical effects of HB 2117 and then provides a broad constitutional history of the federal and Kansas income taxes. Part III argues against the constitutionality of HB 2117 based on the text and history of the Kansas income tax amendment that gave the state legislature the authority to implement an income tax. This Part argues that the text and surrounding history of the amendment do not permit the regressive tax structure that HB 2117 will likely create. Part IV asserts that HB 2117 violates equal protection because it taxes similar taxpayers differently without sufficient justification. Part V argues that HB 2117 unconstitutionally relies on arbitrary federal tax distinctions, and in doing so, impermissibly delegates Kansas legislative authority to a federal administrative agency.

\footnotetext{
* David Barclay. J.D. candidate 2014, University of Kansas School of Law; B.A. 2009, University of Kansas. I would like to thank the legendary Professor Martin Dickinson for his assistance with this Comment and sparking my interest in Kansas tax law. I would also like to thank the entire University of Kansas Law Review staff and board as well as any member of the KU Law community who has suffered through one of my rants regarding Kansas tax policy during the last year.

1. Act of May 22, 2012, ch. 135, 2012 Kan. Sess. Laws 1041.

2. See Kan. Legislative ReSEArch Dep'T, 2012 Summary of LegisLation 129 (2012).

3. See generally Martin B. Dickinson, et al., The Revolutionary 2012 Kansas Tax Act, 61 U. KAN. L. REV. 295 (2012) (describing the practical tax implications of the legislation).
} 


\section{BACKGROUND}

\section{A. Tax Implications of HB 2117}

HB 2117 lowered Kansas income taxes in several ways. ${ }^{4}$ The bill replaced the previous three-bracket structure (with rates of $3.5 \%, 6.25 \%$, and $6.45 \%$ ) with a lower two-bracket structure (with rates of $3.0 \%$ and $4.9 \%$ ) and raised the standard deduction for single filers from $\$ 4,500$ to $\$ 9,000$ and the standard deduction for joint filers from $\$ 6,000$ to $\$ 9,000{ }^{5}$ To partially offset these revenue losses, HB 2117 eliminated the food sales tax rebate and several other credits and deductions including ones related to adoption expenses, alternative fuel equipment, child and dependent expenses, disabled access expenses, and environmental compliance. ${ }^{6}$ HB 2117 also raised revenue by prohibiting renters from claiming the homestead property tax refund and repealing the two-year severance tax exemption for certain sources of oil.

While some of these features set Kansas apart from most states, ${ }^{8}$ the truly "revolutionary" feature of HB 2117 concerns how adjusted gross income (AGI) is calculated for Kansas purposes." Like many other states, Kansas starts with the federal definition of AGI and then modifies this definition as the legislature sees fit. ${ }^{10}$ HB 2117 removed several income sources from the calculation of Kansas AGI, which entirely exempts these sources of income from Kansas taxation. ${ }^{11}$ HB 2117 excludes the following sources of income from the calculation of Kansas AGI beginning January 1, 2013:

\footnotetext{
4. See KAn. Legislative ReSEARCh DeP'T, supra note 2, at 129-30.

5. Id. at 129 .

6. Id.

7. Id. at 130 . The pertinent statute was amended during the 2013 legislative session to specify "that the 50-barrel-per-day threshold [concerning] the new pool severance tax exemption for oil will be determined based on the initial six months of production from each well." See KAN. Legislative Research DeP'T, TAXATION-Summary of Legislation, VARIOUS Provisions; HOUSE SUB. FOR SB 831 (2013).

8. See, e.g., Dickinson et al., supra note 3, at 339. ("Kansas will join Alabama and Mississippi as the only states that impose sales tax on purchases of food but do not provide relief for low-income persons.").

9. See Janet Novack, With Income Tax Changes, Kansas and Maryland Show Their True Colors, FORBES (June 12, 2012), http://www.forbes.com/sites/janetnovack/2012/06/12/with-incometax-changes-kansas-and-maryland-show-their-true-colors/ (noting that while North Carolina already exempted some income from pass-through entities, Kansas is the first state to do so without a cap).

10. Dickinson et al., supra note 3, at 296.

11. See KAN. LegisLAtive RESEARCh DEP'T, supra note 2.
} 
(1) Net profit from business as determined under the federal internal revenue code and reported from schedule $\mathrm{C}$ and on line 12 of the taxpayer's form 1040 federal individual income tax return; (2) net income from rental real estate, royalties, partnerships, S corporations, estates, trusts, residual interest in real estate mortgage investment conduits and net farm rental as determined under the federal internal revenue code and reported from schedule $\mathrm{E}$ and on line 17 of the taxpayer's form 1040 federal individual income tax return; and (3) net farm profit as determined under the federal internal revenue code and reported from schedule F and on line 18 of the taxpayer's form 1040 federal income tax return; all to the extent included in the taxpayer's federal adjusted gross income. ${ }^{12}$

Under this provision, income derived from sole proprietorships, rental real estate, trusts, farms, mineral interests, copyrights, patent royalties, pass-through entities (including limited liability companies (LLCs), partnerships, and S corporations) is no longer subject to Kansas income taxation. ${ }^{13}$ However, capital gains, interest, and qualified dividends attributable to pass-through entities continue to be taxed under the new calculation of AGI. ${ }^{14}$

Kansas Governor Sam Brownback, who championed and signed HB 2117 , contends it will provide economic benefits to the state and called it "a shot of adrenaline into the heart of the Kansas economy." 15 According to Governor Brownback's projections, HB 2117 will generate 22,900 new jobs, provide $\$ 2$ billion more in disposable income, and increase the state's population by 35,740 residents, in addition to the normal growth rate of the state. ${ }^{16}$ Governor Brownback described the portion of HB 2117 that exempts several sources of income from Kansas AGI as "eliminat[ing] state income taxes on more than 191,000 small business owners." 17

One consistent criticism of HB 2117 has been that it will do exactly what Governor Brownback claimed it will do-significantly reduce income tax revenue-leaving the state with a large deficit. ${ }^{18}$ The Kansas

\footnotetext{
12. KAn. Stat. AnN. § 79-32,117(c)(xx) (Supp. 2012).

13. Novack, supra note 9 .

14. See Dickinson et al., supra note 3, at 301-14.

15. Press Release, Kan. Office of the Governor, Governor Brownback Signs Pro-Growth Tax Legislation (May 22, 2012), http://www.ksrevenue.org/pdf/ProGrowthPlan.pdf.

16. $I d$.

17. $I d$.

18. See, e.g., Martin A. Sullivan, Economic Analysis: Brownback's Derailed Tax Reform Becomes a Fiscal Train Wreck, 135 TAX NOTES 1193, 1193 (2012) ("[I]f official revenue estimates are correct, it will force local governments to choose between property tax increases or cuts to education, setting the stage for years of California-style budget crises.").
} 
Legislative Research Department originally estimated that the bill will reduce the state general fund's annual receipts by $\$ 933.7$ million by fiscal year 2018, resulting in a total loss of revenue of approximately $\$ 4.5$ billion between fiscal years 2013 and $2018 .{ }^{19}$ One opponent of the bill described the fiscal effects as "deeper cuts to our public schools, more disabled Kansans left without critical services, and higher property taxes." 20

Another criticism of HB 2117 is that it unfairly shifts the tax burden away from businesses, and not just the small businesses Governor Brownback pointed to when he signed the legislation. ${ }^{21}$ HB 2117 did not include a limit on the amount of business income that can be exempted. ${ }^{22}$ This allows large businesses that are owned by a small number of people to be structured as partnerships, LLCs, or S corporations and escape state income taxation. $^{23}$ The lack of a cap distinguishes HB 2117 from a similar North Carolina law passed in 2011 that capped the exemption at $\$ 50,000 .^{24}$ Critics are also concerned about the distribution of the overall income tax burden after HB 2117 goes into effect. Many high-earning professionals (including doctors, lawyers, accountants, and architects) own their own pass-through entity practices and are therefore exempt from income taxation under HB 2117, while their lower-paid employees will continue to pay. ${ }^{25}$

\section{B. Constitutional History of the Federal Income Tax}

Article I of the U.S. Constitution gives Congress the power to "lay and collect Taxes."26 This power is limited by another provision that reads, "No Capitation, or other direct, Tax shall be laid, unless in Proportion to the Census or Enumeration herein before directed to be taken." ${ }^{27}$ In 1895, the Supreme Court decided Pollock v. Farmers' Loan

19. KAN. LEGISLATIVE RESEARCH DEP'T, supra note 2, at 130.

20. Brent D. Wistrom, Governor Signs Bill for Massive Tax Cuts, WiChita EAGLE, May 23, 2012, http://www.kansas.com/2012/05/22/2344393/governor-signs-bill-for-massive.html (quoting Democratic House Minority Leader Paul Davis).

21. John Hanna, Brownback Chose Not to Push for More Tax Cuts, TOPEKA CAP.-J., August 18, 2012, http:/cjonline.com/news/2012-08-18/brownback-chose-not-push-more-tax-cuts.

22. Dickinson et al., supra note 3 , at 340 .

23. $I d$.

24. Novack, supra note 9.

25. Martin Dickinson, Kansas Tax Act Most Regressive in Nation, LAWRENCE J. WorLD, May 27, 2012, http://www2.ljworld.com/news/2012/may/27/kansas-tax-act-most-regressive-nation/.

26. U.S. CONST. art. I, $\S 8$, cl. 1 .

27. Id. $\S 9, \mathrm{cl} .4$. 
\& Trust Co., which struck down a precursor to the modern federal income tax by finding that it was a "direct tax" that had to be apportioned among the states according to representation. ${ }^{28}$ In response, Congress ratified the Sixteenth Amendment in 1913 which reads, "Congress shall have power to lay and collect taxes on incomes, from whatever source derived, without apportionment among the several States, and without regard to any census or enumeration." 29 Later, in Brushaber v. Union Pacific Rail Road, the Supreme Court confirmed that Congress could implement a progressive income tax under the Sixteenth Amendment. ${ }^{30}$ Brushaber ended any serious doubt regarding the constitutionality of a progressive federal income tax. ${ }^{31}$

\section{History of the Kansas Income Tax}

Kansas first allowed a state income tax after the voters approved a constitutional amendment in $1932 .^{32}$ This amendment is currently codified as article 11, section 2 of the Kansas Constitution and reads, "The state shall have power to levy and collect taxes on incomes from whatever source derived, which taxes may be graduated and progressive." 33

The origins of the Kansas income tax can be traced back to the populist movement of the late $1880 \mathrm{~s}$ and $1890 \mathrm{~s} \mathrm{~s}^{34}$ At that time, state and local property taxes targeted farmers and farmland extensively, while those owning stocks, bonds, and railroads often escaped taxation. ${ }^{35}$ The Populist Party harnessed widespread concern over tax inequality and supported the implementation of a graduated income tax. ${ }^{36}$ The party's efforts originally focused on a graduated income tax at the national

\footnotetext{
28. 158 U.S. 601, 637 (1895), superseded by constitutional amendment, U.S. CONST. amend. XVI.

29. U.S. CONST. amend. XVI.

30. 240 U.S. 1, 24-25 (1916) (upholding the progressive income tax from a challenge on due process grounds).

31. See Leo P. Martinez, "To Lay and Collect Taxes": The Constitutional Case for Progressive Taxation, 18 YALE L. \& POL'Y REV. 111, 131-32 (1999) (“The cases after Brushaber show that the Court has clearly proceeded under the assumption that progressive taxation is constitutionally permissible.").

32. H. Edward Flentue \& Joseph A. Aistrup, Kansas Politics and Government 178 (2010).

33. KAN. CONST. art. XI, § 2.

34. FLENTJE \& AistRUP, supra note 32, at 176 (explaining that during this period "farmers expressed a growing discontent with the inequities of taxes, both state and national").

35. $I d$.

36. Id. at 177 .
} 
level. ${ }^{37}$ Even though progressive legislators voted to ratify the Sixteenth Amendment in 1911, no serious efforts were made towards implementing a state income tax until 1914 when Kansas voters rejected the first income tax amendment. ${ }^{38}$ In 1919, Republican Governor Henry Allen became the first governor to suggest a progressive income tax as a solution to the "inequality in the distribution of the tax burden." 39 Governor Allen convinced the legislature to submit an income tax amendment for approval by the voters, who again rejected it in the election of $1920 .^{40}$

The movement that led to the ultimately successful income tax amendment began in the mid-1920s and was pushed primarily by organized agricultural groups. ${ }^{41}$ The Kansas Farm Bureau, which desired a reduction of property taxes on farmers, endorsed a state income tax beginning in 1924. ${ }^{42}$ Another Governor, Clyde Reed, pledged in his 1928 gubernatorial campaign to "moderniz[e] ... the state system in order to reduce the land-tax load." 43 Again, an income tax amendment was submitted to the voters in the election of 1930, and again, Kansas voters rejected the amendment. ${ }^{44}$

Farm interests, aided by the Kansas Chamber of Commerce, called for resubmission of the income tax amendment during the 1931 legislative session. ${ }^{45}$ The farm lobby found support from the newly elected Governor, Harry Woodring, who called for resubmission of an income tax amendment in order "to lift the part of the load now borne by real and tangible personal property, and so far as possible to distribute it to other forms of wealth which hitherto either in whole or in part have escaped the tax burden."46 Governor Woodring successfully persuaded the legislature to once again submit an income tax amendment to the voters (for the fourth time in less than twenty years) during the 1931

\footnotetext{
37. Id.

38. Id. This 1914 amendment would have eliminated the "uniform and equal" requirement, which would have allowed property to be taxed at different rates and permitted a graduated income tax. Id.

39. Id.

40. Id. This 1920 amendment would have given the legislature "complete freedom from constitutional constraints" on taxation which consequently would have permitted a progressive income tax. Id.

41. $I d$.

42. $I d$.

43. $I d$.

44. $I d$.

45. Id. at $177-78$.

46. Id. at 178 (quoting KeIth D. MCFarland, Harry H. WOOdRING : A POLITICAL BIOGRAPHY OF FDR's CONTROVERSIAL SECRETARY OF WAR 41 (1975)).
} 
legislative session. ${ }^{47}$ Woodring's opponent in the gubernatorial election of 1932, Alf Landon, also supported the income tax amendment ${ }^{48}$ and campaigned on a platform that called for taxes on forms of wealth derived from income and investments. ${ }^{49}$

In the election of 1932, Kansas elected Alf Landon governor and voted to amend the state constitution to allow for the implementation of an income tax by a $58 \%$ to $42 \%$ margin. ${ }^{50}$ Governor Landon took the success of the amendment as a mandate and helped enact the first state income tax on the last day of the 1933 legislative session. ${ }^{51}$ This first Kansas income tax had a graduated structure between $1 \%$ and $4 \%$ for individuals and taxed corporate income at $2 \%{ }^{52}$ The legislature kept the income tax rates at these initial levels until 1957, when it raised them for the first time. ${ }^{53}$ As a result of this new revenue source, property taxes fell from $72 \%$ of state revenue during the 1920 s to $54 \%$ of state revenue between 1930 and $1937 .{ }^{54}$

\section{ARTICLE 11, SECTION 2 OF THE KANSAS CONSTITUTION.}

The Kansas Legislature's current authority to levy an income tax is derived from the income tax amendment of 1932, which is currently codified as article 11 , section 2 of the state constitution. ${ }^{55}$ As explained

\footnotetext{
47. Id.

48. DONALD R. MCCOY, LANDON OF KANSAS 106 (1966).

49. Id. at 95 . The election of 1932 also included the "colorful" third-party candidacy of Dr.
} John R. Brinkley. Id. at 92. Dr. Brinkley acquired a national following and a considerable fortune by surgically transplanting goat-glands into people supposedly to provide the recipient virility. Id. He became a national celebrity and prominent radio host in the region and ran a relatively successful gubernatorial campaign in 1930 in which he received 183,278 votes compared to Woodring's 217,171 votes and the Republican candidate's 216,920 votes. Id. Dr. Brinkley also ran for governor in 1932 and was the only candidate who did not support the income tax amendment. See id. at 91-92, 112.

50. See FlentJE \& AistruP, supra note 32, at 178.

51. Id.

52. $I d$.

53. Id. at 179 .

54. Peter Fearon, Taxation, Spending, and Budgets: Public Finance in Kansas During the Great Depression, 28 KAN. Hist. 235 (2005-06).

55. As a general rule, the state is presumed to possess the power to enforce any legislation it sees fit. See In re ANR Pipeline Co., 79 P.3d 751, 766 (Kan. 2003) ("It is fundamental that the Kansas Constitution limits rather than confers powers."). However, in the particular case of the income tax (as explained below), the legislature apparently did not possess the authority to implement an income tax before the income tax amendment. Consequently, the 1932 income tax amendment can be seen as granting an exception to the underlying presumption against income taxes. This means that the amendment, in a sense, authorized the imposition of an income tax and rendered any income tax that falls outside of article 11, section 2 unconstitutional. 
below, the text of this amendment suggests that the legislature is permitted to implement a flat or "graduated and progressive" income tax, but cannot implement a regressive income tax. According to an originalist interpretation, the history of the income tax amendment also suggests that regressive income taxes are impermissible. HB 2117 enacts a regressive income tax system as a whole, and consequently, it may be seen as unconstitutional according to article 11, section 2 of the Kansas constitution. Additionally, because HB 2117 exempts several types of business and financial income, it is contrary to the intent of those who enacted the provision.

The Kansas Supreme Court has previously relied on the text and original intent of constitutional provisions in determining the validity of statutes. ${ }^{56}$ One statement of this approach reads:

In ascertaining the meaning of a constitutional provision, the primary duty of the courts is to look to the intention of the makers and adopters of that provision. In interpreting and construing the constitutional amendment, the court must examine the language used and consider it in connection with the general surrounding facts and circumstances that cause the amendment to be submitted. A constitutional provision is not to be narrowly or technically construed, but its language should be interpreted to mean what the words imply to persons of common understanding. ... When interpreting the constitution, each word must be given due force and appropriate meaning. ${ }^{57}$

According to this standard of constitutional construction, HB 2117 is unconstitutional if it violates the overall intent of the "makers and adopters" of article 11 , section 2 .

\section{A. HB 2117 Violates the Text of Article 11, Section 2 of the Kansas Constitution.}

According to the Kansas Supreme Court, one appropriate starting point for constitutional construction is to "examine the language used." 58 Article 11, section 2 of the Kansas Constitution reads, "The state shall have power to levy and collect taxes on incomes from whatever source

56. See, e.g., In re Cent. Ill. Pub. Servs. Co., 78 P.3d 419, 426 (Kan. 2003); Bd. of Cnty. Comm'rs v. McGraw Fertilizer Serv., Inc., 933 P.2d 698, 702-03 (Kan. 1997); State ex rel. Stephan v. Finney, 867 P.2d 1034, 1049 (Kan. 1994); Colo. Interstate Gas Co. v. Bd. of Cnty. Comm'rs, 802 P.2d 584, 588-89 (Kan. 1990), superseded by constitutional amendment, KAN. CONST. art. $11 \S 1$, as recognized in In re Cent. Ill. Pub. Servs. Co., 78 P.3d 419 (Kan. 2003)).

57. Stephan, 867 P.2d at 1049 (citations omitted).

58. See id. 
derived, which taxes may be graduated and progressive." $" 59$ According to this language, as explained below, the state cannot levy an income tax that is the opposite of "graduated and progressive." This means the state cannot implement a regressive income tax.

This concept of progressive ${ }^{60}$ versus regressive ${ }^{61}$ tax systems involves the concept of vertical equity (or equality) in taxation. Vertical equity is a description of the relative wellbeing of taxpayers at different income levels under a particular tax scheme. ${ }^{62}$ The debate regarding vertical equity centers on whether it is appropriate for those with higher incomes to pay higher tax rates than do their lower-income counterparts. ${ }^{63}$

According to a textual reading of article 11, section 2, the state cannot enact a regressive income tax system. Without any surrounding historical context, the text of this provision-"The state shall have power to levy and collect taxes on incomes from whatever source derived, which taxes may be graduated and progressive"-suggests three conclusions. First, the state has the power to collect income taxes. The language of the "levy and collect" clause is taken from the federal income tax amendment, which was adopted years before the Kansas income tax amendment. ${ }^{64}$ Second, the state is explicitly permitted to collect "graduated and progressive" income taxes. ${ }^{65}$

Third, the combination of these two phrases suggests that the state cannot enact a regressive income tax structure. The first phrase- " $[\mathrm{t}] \mathrm{he}$ state shall have power to levy and collect taxes on incomes from whatever source derived"-introduces a baseline rule that Kansas is permitted to implement an income tax. The second phrase- "which taxes may be graduated and progressive"-permits a deviation to the

59. KAN. CONST. art. XI, § 2.

60. According to Black's Law Dictionary, a progressive tax is "[a] tax structured so that the effective tax rate increases more than proportionately as the tax base increases, or so that an exemption remains flat or diminishes. With this type of tax, the percentage of income paid in taxes increases as the taxpayer's income increases." 1596 (9th ed. 2009).

61. A regressive tax is "[a] tax structured so that the effective tax rate decreases as the tax base increases. With this type of tax, the percentage of income paid in taxes decreases as the taxpayer's income increases." Id. at 1597.

62. Jim Chen, Progressive Taxation: An Aesthetic and Moral Defense, 50 U. LouISviLle L. REV. 659, 676 (2012).

63. Id.

64. See U.S. CONST. amend. XVI. ("The Congress shall have power to lay and collect taxes on incomes ....")

65. The term "graduated" is closely associated with the term "progressive" in the context of taxation. According to Black's Law Dictionary, it refers to "[a] tax employing a rate schedule with higher marginal rates for larger taxable bases.” 1595 (9th ed. 2009). 
general rule in the direction of progressivity. The combination of these two phrases suggests at minimum that the exact opposite type of deviation (regressivity) is not permitted. If this is not the case, the "graduated and progressive" clause would be redundant because the original clause would have already permitted a progressive income tax.

This conclusion is based on the negative implication embodied in the canon of construction known as expressio unius est exclusion alterius or "expression of the one is exclusion of the other." Ac According to Justice Scalia, a clear application of this canon occurs when a sign instructs that "children under twelve may enter free." 67 According to this canon, everyone who reads this sign knows that thirteen-year-olds may not enter for free. ${ }^{68}$

Additionally, article 11, section 2 suggests that regressive taxes are not permitted even more strongly than Justice Scalia's example. In Justice Scalia's example, the sign discriminates based on age. Age is a category that includes an unlimited number of possibilities. Justice Scalia's sign does not answer whether a senior citizen can enter for free. Conversely, there are only two options within the category of possible deviations from tax equality: a progressive deviation or a regressive deviation. The inclusion of "graduated and progressive" necessarily includes the contemplation of the opposite. Both "progressive" and "regressive" speak to the same trait of vertical tax distribution. An example closer to the situation presented by article 11, section 2 would be a sign reading, "No entry after dark." Because this sign specifically speaks to darkness, the only possible conclusion is that entry while it is light out is permitted according to the text of the sign.

According to a similar canon of construction, when a provision "enumerates a list of exceptions to a power... found in the same [provision], the convention is to treat the list as presumptively exclusive." ${ }^{69}$ Here, article 11, section 2 provides the power to implement an income tax. It then enumerates a specific exception to the general assumption that all taxes are to fall equally by explicitly allowing "graduated and progressive" income taxes. This reading of article 11, section 2 suggests that regressive income taxes are not permitted under the Kansas constitution.

\footnotetext{
66. See ANTONin SCALia, A Matter of INTERPREtATION 25 (1997).

67. Id.

68. Id

69. John F. Manning, The Eleventh Amendment and the Reading of Precise Constitutional Texts, 113 YALE L.J. 1663, 1738 (2004) (citing United States v. Brockamp, 519 U.S. 347, 352 (1997)).
} 
While the Kansas Supreme Court has previously used the concept of negative implication in the context of statutory construction, ${ }^{70}$ many find the canons of construction unpersuasive or worse. ${ }^{71}$

\section{B. HB 2117 Violates the Original Intent of Article 11, Section 2 of the Kansas Constitution.}

According to the originalist approach articulated above in State ex rel. Stephan, the primary goal of the court is to identify the "intention of the makers and adopters" of a provision. ${ }^{72}$ While the court uses the text of the provision, it also looks to the "general surrounding facts and circumstances that cause[d] the amendment to be submitted." 73 If a Kansas court were to apply this standard to article 11, section 2, it would likely conclude that the historical surroundings of this provision also suggest a prohibition on regressive income taxation.

There is substantial historical evidence to suggest that there was an assumption of equal income taxation in Kansas because of the "uniform and equal" clause ${ }^{74}$ of the Kansas Constitution. According to this understanding, even a flat income tax violated the "uniform and equal" clause. When the voters ratified the Kansas income tax amendment, they implicitly rejected regressive income taxation.

An appropriate starting point for determining what the "makers and adopters" of article 11, section 2 intended is to look to the public pronouncements of Governor Woodring who persuaded the Kansas legislature to refer the successful income tax amendment to the voters. ${ }^{75}$ The Governor outlined his reasons for supporting the amendment during his address to the legislature in 1931:

Students of American tax problems have long been familiar with the fact that our systems have not kept pace with economic developments in our nation. Seventy years ago when our tax system in Kansas was devised practically all property consisted either of real estate or other visible property and tangible property....

\footnotetext{
70. E.g., State ex rel. Stovall v. Meneley, 22 P.3d 124, 146 (Kan. 2001) ("K.S.A. 60-521, by negative implication, retains governmental immunity from the statute of limitations for causes of action arising out of a governmental function.").

71. See SCALIA, supra note 66 , at $25-26$ ("[I]n fact, the canons have been attacked as a sham ....").

72. 867 P.2d 1034, 1049 (Kan. 1994).

73. $I d$.

74. The modern version of this clause is codified at KAN. CONST. art. XI, § 1 .

75. FLENTJE \& AISTRUP, supra note 32, at 176-78.
} 
To-day the situation is entirely changed. Economic evolution has brought about a vast increase of intangible property - stocks, bonds, moneys, notes - most of which escapes the assessor; especially since we attempt to levy on this class of property the ad volorem or full rate of the general property tax. Real and tangible property is no longer the sole index of wealth in our state....

In the absence of authority to enact a graduated income tax law, I considered recommending to the legislature the passage of a flat income tax law with deductions of twenty-five dollars to relieve small incomes, and with further provision for the deduction of amounts paid in general property taxes. I have, however, been informed that such a law would be a violation of the "uniform and equal" clause of our constitution and therefore abandoned the income tax as a source of revenue until the constitution shall have been amended. ${ }^{76}$

Two propositions emerge from this source. It appears the overall purpose of the income tax amendment was to update the state's system of collecting revenue to keep pace with the economic shift from land to financial assets as the primary source of wealth. Additionally, it is clear that Governor Woodring did not believe he had the ability to levy either a flat income tax or a progressive income tax because of the "uniform and equal" clause of the constitution.

Other sources are consistent with these two takeaways regarding the "intention[s] of the makers and adopters" of article 11, section 2. One Kansas newspaper, the Lawrence Journal-World, explained this amendment to the voters (or the adopters) at the time:

Amendment No. 1 The Income Tax Amendment

Proposes to give the legislature authority to pass a graduated income tax, thereby shifting a part of the burden of taxes from real estate owners to those who are more able to bear it.

a. This would tax salaries, incomes from investments, interest, etc., and make it possible to reduce taxes on farms and homes.

b. It would levy tax according to the ability of the individual to pay.

76. Governor Harry Woodring, Message of Governor Harry H. Woodring to the Legislature of 1931, 6-8 (Jan. 14, 1931). 
c. It is considered sound by authorities of tax problems, and is in use in other states.

Another newspaper described the amendment as authorizing "the state to levy graduated and progressive income taxes from whatever source derived." 78 Yet another newspaper described the amendment as the "Graduated Income Tax Amendment.",79

An advertisement in support of Governor Woodring highlighted his support for the amendment and described its benefits as increasing "the state's revenue from larger incomes, thereby relieving the tax burden on the farmer and home owner." 80 Another public advocate complained about the distribution of the state's tax system prior to the amendment. He contended that farmers paid an average of $44 \%$ of their income, retired citizens paid $27.5 \%$, businesspeople paid $10 \%$, professionals paid $10 \%$, bank officers paid $3.5 \%$, and teachers paid $2.9 \%$ of their income in state taxes. ${ }^{81}$ He also complained that those currently exempt from taxation were not the "needy ones" but "the ones best able to pay., 82 Additionally, fifteen years after the election that ratified the income tax amendment, the Kansas Supreme Court commented, "We need not dwell on the fact that the purpose of the income tax law was to provide for a graduated and progressive tax on income ...."83

All of this evidence supports the proposition that Kansas income taxes are permitted to be either flat or "graduated and progressive," but not regressive. Those who supported the successful income tax amendment in 1932 (the "makers and adopters" of the provision) favored the amendment because it allowed the legislature to implement a particular type of tax structure. That new income taxes could be and would be progressive, and thus redistribute the tax burden, was the focal

77. The Facts About the Tax Amendments to Be Submitted to the Voters of Kansas on Nov. 8, LAWRENCE J.-WORLD, Oct. 19, 1932, at 2. The income tax amendment was submitted with another amendment that would have placed constitutional limits on property taxes. See id.

78. Income Tax Is Approved, WeEKLY KAN. CitY STAR, Nov. 9th, 1932, at 2.

79. Kansas Voters Adopt Income Tax, 3 to Two, TOPEKA DAILY CAP., Nov. 11, 1932, at 1.

80. Vote for Woodring and the Income Tax Amendment, WeEkLy KAN. CiTY STAR, Nov. 2, 1932, at 9. The advertisement primarily targets the third-party candidate Dr. Brinkley (who did not support the income tax) instead of the eventual winner, Republican Alf Landon. Id.

81. W.H. Finney Attacks Present Tax System, TopeKa DaILy CAP., Nov. 1, 1932, at 7.

82. Id. ("If the unemployed, the unfortunate, the needy and those in distress were the ones who are not now called on to pay their share of the cost of government, we would agree that at this time nothing should be done about it. But such is not the case. A study of the assessors' returns indicate that those now exempt are not the needy ones. In fact, they are the ones best able to pay, and far more able than the real estate owner who now foots the bill of government expenses.")

83. Hartman v. State Comm'n of Revenue and Taxation, 187 P.2d 939, 944-45 (Kan. 1947). 
point of the amendment. These sources clearly indicate that a regressive income tax would likely not be permissible under the amendment according to the intent of its "makers and adopters." The first Kansas state income tax was "graduated and progressive," as has been every income tax since. ${ }^{84}$ It is unlikely that the very opposite type of income tax, which would accomplish the opposite of what the amendment's supporters intended, would be permitted under this amendment.

One possible counterargument to this analysis turns on the Uniform and Equal Clause of the Kansas Constitution ${ }^{85}$ and whether it currently applies to Kansas income taxes. This argument would contend that because the Uniform and Equal Clause did not limit income taxes at the time of the amendment or does not limit them now, there are no constitutional constraints on the legislature's ability to implement a regressive income tax because the state is presumed to have all power not restricted by the constitution. ${ }^{86}$ This would mean that while article 11 , section 2 specifically allows for a "graduated and progressive" income tax, it does not necessarily preclude the imposition of a regressive income tax. There is some support for this argument. The Kansas Supreme Court in a 1947 case stated that the Uniform and Equal Clause did not apply to the income tax. ${ }^{87}$ Additionally, some secondary sources have also concluded that the Uniform and Equal Clause does not apply to income taxes in Kansas. ${ }^{88}$ However, this counterargument fails for two reasons.

First, the historical evidence strongly suggests that the Uniform and Equal Clause was thought to apply at the time of the 1932 amendment. Governor Woodring explicitly said he was prevented from implementing even a flat income tax because of the Uniform and Equal Clause. ${ }^{89}$ Also, that the Kansas Legislature submitted the income tax amendment four separate times, in the elections of $1914,1920,1930,1932,{ }^{90}$ strongly

84. See FLENTJE \& AISTRUP, supra note 32, at 179.

85. KAN. CONST. art. XI, $\S 1$.

86. Cf. In re ANR Pipeline Co., 79 P.3d 751, 766 (Kan. 2003) (presenting a similar argument in the context of the taxation of public utility intangibles).

87. Hartman, 187 P.2d at 944 ("We pause here to note the taxpayer's contention that previous decisions of this court, including the last case, leading to a conclusion that an income tax is an excise tax and not subject to provisions of Art. 11, $\S 1$, appear to be impeached by our decision .... We think not." (citing Natural Gas Pipe Line Co. v. State Comm'n of Revenue and Taxation, 125 P.2d 397 (Kan. 1942)).

88. See, e.g., 1 WAdE Newhouse, Constitutional Uniformity and Equality In State TAXATION 508 ( 2 d ed. 1984) (concluding that an income tax is an excise tax that did not fall under the restrictions of the Uniform and Equal Clause).

89. See supra note 76 and accompanying text.

90. See supra notes $38-51$ and accompanying text. 
suggests it did not possess the authority to pass an income tax without constitutional amendment. Both of these sources indicate the Uniform and Equal Clause was thought to apply at the time of the amendment.

Second, even if the Uniform and Equal Clause did not apply to income taxes at the time of the amendment, or does not apply to income taxes now, the history surrounding article 11 , section 2 seems to presume equality in taxation. If this is the case, then article 11 , section 2 can be seen as implicitly prohibiting the implementation of a regressive income tax. When the voters decided to specifically allow for a graduated income tax, they implicitly restricted the opposite type of tax. According to both the text of article 11, section 2 and the intentions of the "makers and adopters" of the amendment, the Kansas legislature is prohibited from implementing a regressive income tax.

\section{HB 2117 Creates a Regressive Income Tax Overall and Is Therefore Unconstitutional}

On its face, HB 2117 purports to maintain a progressive tax structure. ${ }^{91}$ In actuality, it will likely create a regressive income tax system as a whole. ${ }^{92}$ The truly regressive feature of HB 2117 is the unlimited exemption of several types and sources of income. ${ }^{93}$ It allows for an unlimited amount of certain sources of income to be entirely excluded from Kansas income taxation. ${ }^{94}$ Very wealthy Kansans who receive their entire incomes from certain sources will pay a Kansas income tax rate of $0 \%$. Other commenters have concluded that the effect of this exemption will almost certainly be to "transform the Kansas income tax into a regressive system, with lower-income Kansans cumulatively paying a higher percentage of their income in tax than will higher-income Kansans." 95

While Kansas will certainly have a less progressive income tax after HB $2117,{ }^{96}$ the constitutional question is whether the Kansas income tax

\footnotetext{
91. See Kan. Legislative Research DeP'T, supra note 2.

92. Dickinson et al., supra note 3, at 340.

93. Id.

94. Id.

95. Id.

96. HB 2117 reduced the top tax rate from $6.45 \%$ to $4.9 \%$ (a $24 \%$ decrease), reduced the $6.25 \%$ rate to $4.9 \%$ (a $22 \%$ decrease), and reduced the lowest rate from $3.5 \%$ to $3.0 \%$ (a $14 \%$ decrease). Sullivan, supra note 18, at 1194. One study by the Institute on Taxation and Economic Policy (which took into account not only rate reductions but also the eliminations of deductions and credits) estimated that the poorest $20 \%$ of Kansans, with an average annual income of $\$ 11,000$, will see their taxes increase under HB 2117 by $1.3 \%$ per year. InST. ON TAXATION \& ECON. POLICY,
} 
is regressive as a whole after the bill. However, it is difficult to identify at precisely what point an income tax becomes regressive. Is an income tax regressive when the top one percent of earners pay a lower percentage of their income than the bottom ninety-nine percent? Is an income tax regressive when just a few very-high earners pay a lower effective rate than others? Does every taxpayer who earns more than any other taxpayer have to pay a higher percentage of her income for a system to be progressive? Without establishing a precise proportional definition, it is reasonable to conclude that HB 2117 implements a regressive state income tax system as a whole.

Many very wealthy people will no longer pay Kansas income taxes after HB 2117. While the proponents of HB 2117 claimed it would exempt small business owners, ${ }^{97}$ it is certain to also exempt owners of some large businesses as well. Nationwide in 2009, 188,656 taxdesignated $\mathrm{S}$ corporations netted over $\$ 1$ million in income along with 199,566 partnerships and 25,550 nonfarm sole proprietorships. ${ }^{98}$ The owners of these businesses who live in Kansas will no longer pay state income tax on these sources of income. The Institute on Taxation and Economic Policy has studied the likely effects of HB 2117 and concluded it will distribute Kansas income taxes according to the following table (based on 2010 income). ${ }^{99}$

\section{Table 1}

\begin{tabular}{|l|l|l|l|l|l|l|l|}
\hline $\begin{array}{l}\text { Income } \\
\text { Group }\end{array}$ & $\begin{array}{l}\text { Lowest } \\
20 \%\end{array}$ & $\begin{array}{l}\text { Second } \\
20 \%\end{array}$ & $\begin{array}{l}\text { Middle } \\
20 \%\end{array}$ & $\begin{array}{l}\text { Fourth } \\
20 \%\end{array}$ & Next 15\% & Next 4\% & Top 1\% \\
\hline $\begin{array}{l}\text { Income } \\
\text { Range }\end{array}$ & $\begin{array}{l}\text { Less } \\
\text { than } \\
\$ 19,000\end{array}$ & $\begin{array}{l}\$ 19,000 \\
-\end{array}$ & $\begin{array}{l}\$ 36,000 \\
-\end{array}$ & $\begin{array}{l}\$ 55,000 \\
-\end{array}$ & $\begin{array}{l}\$ 88,000 \\
-\end{array}$ & $\begin{array}{l}\$ 165,000 \\
-\end{array}$ & $\begin{array}{l}\$ 400,000 \text { or } \\
\text { more }\end{array}$ \\
\hline $\begin{array}{l}\text { Average } \\
\text { Income } \\
\text { in Group }\end{array}$ & $\$ 10,300$ & $\$ 28,000$ & $\$ 45,500$ & $\$ 71,200$ & $\$ 115,100$ & $\$ 233,300$ & $\$ 1,025,300$ \\
\hline $\begin{array}{l}\text { Kansas } \\
\text { Personal } \\
\text { Income }\end{array}$ & & & & & & & \\
\hline
\end{tabular}

Tax Bill Signed By Governor Brownback Makes Kansas an Outlier (2012), http://www.itep.org/pdf/KSFamilies.pdf. According to this study, "[t]he middle 20 percent of Kansas taxpayers will pay 0.5 percent less of their income in taxes" and the wealthiest one percent's taxes will drop by $2 \%$ per year (for an average savings of \$21,087). Id.

97. Press Release, supra note 15.

98. See Joint Comm. on TAxation, Selected Issues Relating to Choice of Business ENTITY 17 (2012), available at https://www.jct.gov/publications.html?func=startdown\&id=4402.

99. Inst. On TAXATION \& ECON. Policy, Who PAys? A Distributional ANAlysis of the TAX SYSTEMS IN ALL 50 STATES 58 (4th ed. 2013), http://www.itep.org/pdf/whopaysreport.pdf. 


\begin{tabular}{|l|l|l|l|l|l|l|l|}
\hline $\begin{array}{l}\text { Income } \\
\text { Group }\end{array}$ & $\begin{array}{l}\text { Lowest } \\
20 \%\end{array}$ & $\begin{array}{l}\text { Second } \\
20 \%\end{array}$ & $\begin{array}{l}\text { Middle } \\
20 \%\end{array}$ & $\begin{array}{l}\text { Fourth } \\
20 \%\end{array}$ & Next 15\% & Next 4\% & Top 1\% \\
\hline $\begin{array}{l}\text { Tax } \\
\text { Share of } \\
\text { Family } \\
\text { Income } \\
\text { (Kansas) }\end{array}$ & $-0.2 \%$ & $0.8 \%$ & $1.9 \%$ & $2.4 \%$ & $3.0 \%$ & $2.9 \%$ & $2.4 \%$ \\
\hline $\begin{array}{l}\text { State } \\
\text { Personal } \\
\text { Income } \\
\text { Tax } \\
\text { Share of } \\
\text { Family } \\
\text { Income } \\
\text { (National } \\
\text { Average) }\end{array}$ & $0.2 \%$ & $1.4 \%$ & $2.2 \%$ & $2.7 \%$ & $3.1 \%$ & $3.6 \%$ & $4.3 \%$ \\
\hline
\end{tabular}

While these are preliminary estimates of how HB 2117 will redistribute the Kansas income tax, this table suggests that HB 2117 will create a regressive income tax system as a whole. While these findings may not seem particularly regressive at first glance, this would be a relatively regressive income tax system compared to other states ${ }^{100}$ and the federal income tax. ${ }^{101}$ The Kansas income is likely to be regressive even compared to states with constitutional mandates of flat income taxation, such as Illinois. ${ }^{102}$

A natural counterargument to this proposed restriction on regressivity is that income taxes are inherently complex and policydriven and therefore should be left to the legislature. While tax policy is certainly the legislature's duty, the Kansas Supreme Court recently involved itself in similar policy-driven matter when it required levels of education funding because of another provision in the Kansas Constitution. ${ }^{103}$ A prohibition against income tax regressivity as a whole would require far less judicial policymaking than happened in the education-funding context. A court could simply strike down laws that create regressive income tax schemes instead of having to continuously monitor whether the state legislature was meeting an affirmative duty.

\footnotetext{
100. Id.

101. See generally David S. Logan, SUMmary of LATEST Federal Individual Income TAX DATA 3 (2011), http://taxfoundation.org/sites/taxfoundation.org/files/docs/ff285.pdf.

102. InST. ON TAXATION \& ECON. POLICY, supra note 99, at 52; see also ILl. CONST. art. IX, $\$ 3$ ("A tax on or measured by income shall be at a non-graduated rate. At any one time there may be no more than one such tax imposed by the State for State purposes on individuals and one such tax so imposed on corporations.").

103. See Richard E. Levy, Gunfight at the K-12 Corral: Legislative v. Judicial Power in the Kansas School Finance Litigation, 54 U. KAN. L. REV. 1021, 1021 (2006) (explaining that the school-finance litigation was a confrontation between the courts and the Kansas legislature).
} 


\section{HB 2117 Unconstitutionally Frustrates the Intent of the Income Tax} Amendment

In a broader sense, HB 2117 frustrates the original intent of the Kansas income tax amendment because it exempts several types of business and financial income under the authority of an amendment that was at least partially meant to tax these types of assets. ${ }^{104}$ Vertical equity was also a concern at the time of the amendment's passage. As the historical sources noted above indicate, the purpose of the income tax amendment was to give the state the authority to tax employees, business people, and financial assets because land was no longer the primary measurement of wealth in the twentieth-century economy. ${ }^{105}$ While employees are still subject to Kansas income taxes after HB 2117, many types of business owners are now exempt. This seems to warp the intentions of the "makers and adopters" of the article 11, section 2 . If original intent means anything, it should stand for the proposition that the state cannot rely on constitutional authority to accomplish the exact opposite of what the drafters of a provision intended. Article 11, section 2 was at least partially designed to tax the newly dominant forms of wealth, business, and financial assets. HB 2117 exempts many of these types of assets and, in doing so, frustrates the original intent behind article 11, section 2 of the Kansas Constitution.

\section{EQUAL PROTECTION}

Even if a court were to find these historical and textual arguments regarding article 11, section 2 unpersuasive, HB 2117 may violate equal protection according to any of three lines of precedent. First, a state or federal court could conclude that HB 2117 furthers an improper purpose because it explicitly favors one (relatively politically powerful) class of income earners over another. Second, a court could decide that HB 2117 violates equal protection because it results in highly unequal tax treatment of similarly situated taxpayers. Third, a court could find that HB 2117 creates arbitrary tax distinctions that are unrelated to the furtherance of a legitimate state policy objective.

104. See supra notes $76-84$ and accompanying text.

105. See, e.g., Woodring, supra note 76 ("To-day the situation is entirely changed. Economic evolution has brought about a vast increase of intangible property - stocks, bonds, moneys, notesmost of which escapes the assessor... Real and tangible property is no longer the sole index of wealth in our state."). 
While Part III of this Comment argues that HB 2117 violates article 11 , section 2 because it violates a presumption of vertical equity, this Part argues that HB 2117 runs contrary to notions of horizontal equity; the idea that similarly situated taxpayers should bear roughly equal tax burdens. ${ }^{106}$ HB 2117 violates the principle of horizontal equity in several instances. For example, a cardiologist who owns a partnership in her practice pays no state income tax (under HB 2117) while a cardiologist who works as a hospital employee will pay state income tax on her entire income. ${ }^{107}$ Similarly, a law partner working as a criminal defense counsel pays no state income taxes under HB 2117 while her opponent in court, a state prosecutor, will pay state income taxes as an employee. ${ }^{108}$ There are also horizontal equity concerns with HB 2117 because it taxes some passive types of investments (stocks and bonds), but entirely exempts other types of passive investment (real estate rent, mineral royalties, passive farm income) from state income taxation. ${ }^{109}$ These distinctions are contrary to federal precedent ${ }^{110}$ and treat similarly situated taxpayers grossly differently under the law.

\section{A. Tax Distinctions Under Equal Protection}

Different treatment of essentially similar taxpayers implicates review under the equal protection guarantee of the U.S. and Kansas Constitutions. Equal protection review, (under the Kansas Constitution Bill of Rights section 1) is implicated when "a statute treats arguably indistinguishable classes of people differently." 111 Put another way, an equal protection challenge must be based on an instance where "persons classified by the enactment are similarly situated to those who were excluded from the classification." 112 The Kansas Supreme Court has previously granted equal protection review to a petitioner challenging the validity of the deferential income tax treatment between single and married taxpayers. ${ }^{113}$ This is an appropriate analogy to the situation presented by HB 2117 because single and married are different statuses

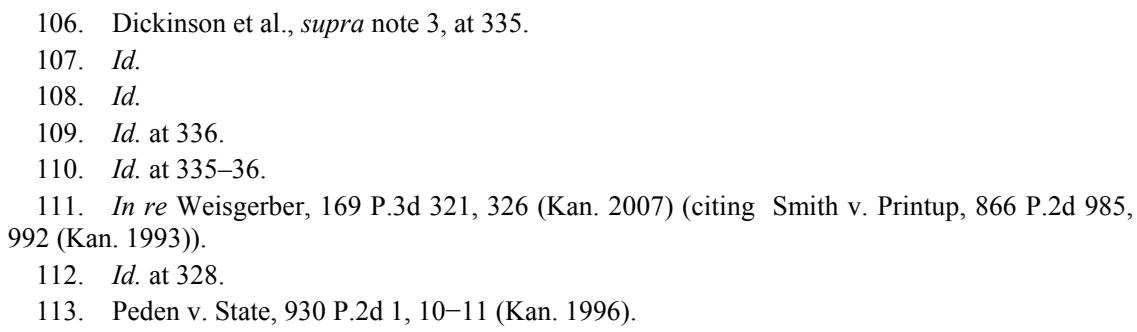


in a legal sense, as are employees and sole-proprietors, but may be essentially similar in other regards. ${ }^{114}$

Another consideration is that any potential challenger to HB 2117 would be harmed by the law only relative to the tax treatment of others. The Kansas Supreme Court has specifically addressed this issue and determined that relatively unfair taxation can constitute a violation of equal protection. ${ }^{115}$ The court concluded, "If similarly situated taxpayers receive disparate treatment, the one receiving the less favorable treatment may have been denied equal protection of the law even if the taxpayer receiving the less favorable tax is taxed according to the law."116 According to this precedent, HB 2117 is subject to equal protection review even though it actually benefits, rather than harms, certain groups.

Under equal protection, rational basis review is the appropriate standard when a law does not target a "suspect class or burden a fundamental right." "117 The Kansas Supreme Court explained this rational basis standard:

The [rational basis] test is violated only if the statutory classification rests on grounds wholly irrelevant to the achievement of the State's legitimate objective. The state legislature is presumed to have acted within its constitutional power, even if the statute results in some inequality. Under the [rational basis] test, a statutory discrimination will not be set aside if any state of facts reasonably may be conceived to justify it.

This standard creates two requirements for HB 2117 to be upheld. The bill must further a "legitimate objective" and the means chosen to pursue that objective must not be "wholly irrelevant" to its achievement. Furthermore, because HB 2117 involves tax classifications, courts are even more deferential. ${ }^{119}$

When Governor Brownback signed HB 2117, he provided five legitimate objectives that the law furthers. ${ }^{120}$ Governor Brownback and other supporters contend HB 2117 will: (1) improve the Kansas

\footnotetext{
114. Id. at 10 .

115. In re City of Wichita, 59 P.3d 336, 341-42 (Kan. 2002) (citing Colo. Interstate Gas Co. v. Beshears, 24 P.3d 113, 113 (Kan. 2001)).

116. Id.

117. Downtown Bar \& Grill, LLC v. State, 273 P.3d 709, 714-15 (Kan. 2012) (quoting State v. Stallings, 163 P.3d 1232, 1239 (Kan. 2007)).

118. Peden, 930 P.2d at 10-11 (quoting Leiker v. Gafford, 778 P.2d 823, 849 (Kan. 1989)).

119. See id. at 11 (quoting Madden v. Kentucky, 309 U.S. 83, 88 (1940)).

120. Press Release, supra note 15.
} 
economy; (2) provide jobs; (3) increase taxpayers' disposable income; (4) increase the Kansas population; and (5) help small businesses. ${ }^{121}$ Any challenger under the rational basis equal protection standard would not only have to negate these objectives, but would also have to negate any other conceivable justification for the distinctions within the law. ${ }^{122}$ There are three lines of precedent a court could rely on to conclude that HB 2117 violates equal protection.

\section{B. HB 2117 Advances an "Improper Purpose"}

First, a state or federal court could decide that HB 2117 advances an "improper purpose" of advantaging one group over another without a greater benefit to society. This is related to the general constitutional prohibition against "naked preference" in the law.

Within this first, "improper purpose," line of cases, the U.S. Supreme Court has struck down laws under rational basis review when it perceived the law to be a disguised attempt to harm a politically unpopular or powerless group. ${ }^{123}$ This was the situation in USDA $v$. Moreno, in which the U.S. Supreme Court struck down amendments to food stamp eligibility because they appeared to target "hippies" instead of targeting those who were specifically likely to abuse the program. ${ }^{124}$ Similarly, in City of Cleburne v. Cleburne Living Center, the U.S. Supreme Court struck down a law requiring a special permit for a mentally disabled home because the law seemed "to rest on an irrational prejudice against the mentally retarded." 125 Finally, in Romer v. Evans, the U.S. Supreme Court struck down a Colorado law that prohibited local governments from enacting anti-discrimination ordinances that protected homosexuals. ${ }^{126}$

In these cases, the Court seemed to apply a heightened level of scrutiny (while still under rational basis review) that was minimally deferential to the legislative branch and found that the challenged law

\footnotetext{
121. Id.

122. Peden, 930 P.2d at 11 ("Under the [rational] basis test, it is unnecessary to ascertain the specific purpose the Kansas Legislature espoused, if any, in establishing the challenged classification. Rather, if any state of facts reasonably may be conceived to justify the alleged statutory discrimination, the statute will not be set aside as a violation of equal protection." (quoting Bair v. Peck, 811 P.2d 1176, 1184 (Kan. 1991)).

123. Robert C. Farrell, The Two Versions of Rational-Basis Review and Same-Sex Marriage, 86 WASH. L. REV. 281, 298-99 (2011).

124. 413 U.S. $528,537-38(1973)$

125. 473 U.S. 432,450 (1985).

126. 517 U.S. $620,635-36(1996)$.
} 
was really an attempt to penalize an unpopular group. ${ }^{127}$ The U.S. Supreme Court explained this more demanding version of rational basis review in Moreno:

For if the constitutional conception of "equal protection of the laws" means anything, it must at the very least mean that a bare congressional desire to harm a politically unpopular group cannot constitute a legitimate governmental interest. ${ }^{12}$

The Kansas Supreme Court has also indicated support for this "improper purpose" type of analysis:

Under the rational basis test, great deference is given to the legislature in establishing classifications. However, where, as here, the only basis for the classification is to deny a benefit to one group for no purpose other than to discriminate against that group, the statutory classification is ... without a rational basis . ... ${ }^{129}$

This federal and state precedent establishes that a law is vulnerable under equal protection when its purpose is to harm or disadvantage a particular group. This "improper purpose" precedent, combined with the Kansas precedent that applies equal protection review to unfair benefits, suggests that states can violate equal protection by unfairly benefitting a particularly powerful group.

While not typically included in this "improper purpose" line of federal precedent, Zobel v. Williams is also pertinent to this analysis because it involves purely economic discrimination and not larger issues of social exclusion. ${ }^{130}$ Zobel was an equal protection challenge to an Alaskan statute that distributed funds from state-owned oil resources to citizens based on how long they had resided in Alaska. ${ }^{131}$ Under this statute, a resident who had lived in Alaska for one year received a \$50 payment each year while someone who had lived in Alaska since it became a state in 1959 received a $\$ 1,050$ payment. ${ }^{132}$

The Alaskan Supreme Court upheld the law because it advanced the purpose of acknowledging "contributions of various kinds, both tangible and intangible, which residents have made during their years of

127. Farrell, supra note 123, at 298.

128. Moreno, 413 U.S. at 534.

129. Thompson v. KFB Ins. Co., 850 P.2d 773, 782. (Kan. 1993).

130. 457 U.S. 55 (1982).

131. Id. at 57.

132. Id. 
residency."133 The U.S. Supreme Court analyzed this statute under rational basis review and concluded that acknowledgment of past civic contributions was not a "legitimate state purpose." 134 In doing so, the Court noted that allowing a state to give payments for past accomplishments would allow a state to be divided up into different classes of residents. ${ }^{135}$

According to this "improper purpose" line of cases, HB 2117 is constitutionally vulnerable even under rational basis review. The law can be seen as either unfairly burdening those who will continue to pay state income taxes (many of whom are less economically powerful than entity owners) or unfairly benefitting an entire class of entity owners and certain types of passive investors.

The supporters of HB 2117 suggest that the law's disparate treatment of certain groups would improve the Kansas economy and increase Kansans' disposable income. ${ }^{136}$ But HB 2117 furthers these purposes by specifically favoring one type of compensation arrangement over another, without regard to the substantive services provided by each group. ${ }^{137}$ Unlike other government subsidies or tax breaks, HB 2117 discriminates solely based on form with no consideration of the larger effects that business will have on society. This is contrary to federal law, which generally taxes personal service income at the same rate, regardless of whether the income is earned as an employee, independent contractor, or partner. ${ }^{138}$

The Kansas Supreme Court has previously acknowledged an equal protection prohibition against distinctions based on mere ownership in the context of property tax exemptions. In In re Central Illinois Public Services Co., the court reasoned that property tax exemptions based on who owns a particular piece of property would violate equal protection because classification based on ownership "discriminates against one citizen in favor of another." 139 This seems to prohibit tax distinctions based on status, as opposed to substantive or real-world function. As a

\footnotetext{
133. Id. at 61, 63 (quoting Williams v. Zobel, 619 P.2d 448, 458 (Alaska 1980)).

134. Id. at 63 .

135. Id. at 64 .

136. Press Release, supra note 15.

137. Dickinson et al., supra note 3, at 336 ("Much of the disparity in treatment among taxpayers arises from the fact that [HB 2117] isolates tax benefits based on source and entity, rather than the nature of the underlying income.").

138. Id. at $335-36$.

139. 78 P.3d 419, 427 (Kan. 2003) (quoting State ex rel. Stephan v. Parrish, 891 P.2d 445, 452 (Kan. 1995)).
} 
result, this standard of equal protection would seem to prohibit HB 2117 because it discriminates entirely based on who the person filing the tax form is, rather than what the person filing the form does. The idea that the U.S. Constitution prohibits this type of raw favoritism has been recognized as an important principle in many areas of constitutional law. ${ }^{140}$ One prominent scholar, Cass Sunstein, has described this broad principle:

Although [several constitutional] clauses have different historical roots and were originally directed at different problems, they are united by a common theme and focused on a single underlying evil: the distribution of resources or opportunities to one group rather than another solely on the ground that those favored have exercised the raw political power to obtain what they want. ${ }^{141}$

Accordingly, equal protection rational basis review can be seen as a weak version of this constitutional prohibition against "naked preference." 142

There are several possible counterarguments to this equal protection argument. One could argue that Kansas wage-earners do not constitute a similar class to hippies, the mentally disabled, or homosexuals. These classes are based on characteristics that are socially distinct and arguably define who someone is rather than what she chooses to do. Choice of business entity could be seen as a less socially important trait. This argument would contend that any unfavored employee could choose to start a favored business entity and receive the tax benefits from HB 2117. However, the U.S. Supreme Court has recognized an individual right to carry out one's chosen profession, ${ }^{143}$ and several professions simply cannot be performed as an independent contractor or sole proprietor. It is impossible to be a sole proprietor police officer, judge, prosecutor, or teacher. In this sense, HB 2117 can be seen as specifically discriminating against professions that require employee status.

140. Cass R. Sunstein, Naked Preferences and the Constitution, 84 Colum. L. REV. 1689, 1689 (1984).

141. Id.

142. Id. at 1713 .

143. See, e.g., United Bldg. \& Constr. Trades Council v. Mayor of Camden, 465 U.S. 208, 221-22 (1984) (determining that workers' right to seek employment with city contractors was "sufficiently basic to the livelihood of the Nation" to fall within the protections of the Privileges and Immunities Clause); In re Griffiths, 413 U.S. 717, 720 (1973) ("It requires no argument to show that the right to work for a living in the common occupations of the community is of the very essence of the personal freedom and opportunity that it was the purpose of the (Fourteenth) Amendment to secure.” (quoting Truax v. Raich, 239 U.S. 33, 41 (1915)) (alteration in original)). 
Another possible counterargument is that the groups previously protected in the "improper purpose" category were all small minorities, while employees constitute a large population within Kansas. This argument can be dismissed because these cases can all be read as disadvantaging democratically unpopular groups. While the previous groups were not democratically powerful because of relatively small numbers, Kansas employees can be seen as not democratically powerful because of their relatively small economic influence. While many notwealthy and relatively powerless independent contractors and small business owners will benefit from HB 2117, as discussed above, the legislation will provide the largest benefits to the most-wealthy Kansans. If a court were to refuse to consider those who will continue to pay state income taxes as a sufficient class to invoke the "improper purpose" precedent, it would allow a small number of politically powerful individuals to favor themselves without even purporting to benefit the greater good.

Another possible counterargument is that the difference in tax treatment of capital gains and employment income under federal law is an example where similar discrimination already occurs. ${ }^{144}$ There are two reasons why this argument fails. First, this disparate treatment is based on substantive, real-world differences in how the income was earned and the federal government generally tries to keep the classifications consistent. ${ }^{145}$ Generally, passive income is taxed at a lower rate than active income earned from labor. ${ }^{146}$ Here, HB 2117 discriminates on exactly the opposite principle. It taxes income differently not based on any substantive difference, but based on the form in which the income is received. Second, there is difference in treatment between earned income and capital gains but only to an extent under federal tax law. Under HB 2117, there is an infinite tax disparity between employees and those who receive the newly exempt sources of income. Favoring those who receive certain types of income without regard to underlying, substantive differences is an improper purpose under equal protection.

\footnotetext{
144. See Dickinson et al., supra note 3, at 335-36.

145. Id. at 336 .

146. Id.
} 


\section{HB 2117 Under Federal Tax Precedent}

A state or federal court could also rely on another line of federal cases in overturning HB 2117 as a violation of equal protection. In Allegheny Pittsburgh Coal Co. v. County Commission, a business challenged a local property tax assessment on equal protection grounds. ${ }^{147}$ The county assessor had valued property on the basis of its most recent purchase price and made only small adjustments to the assessments of land that had not been recently sold. ${ }^{148}$ Over time, this system created large disparities between recent and longtime landowners. ${ }^{149}$ The plaintiff, Allegheny Pittsburgh Coal Company, was taxed at approximately thirty-five times the rate of similar landowners. ${ }^{150}$

The U.S. Supreme Court found this local tax assessment system unconstitutional in light of the West Virginia Constitution, which required that property must be taxed at a uniform rate. ${ }^{151}$ The Court reasoned that the constitutional infringement came not from the overall rate of taxation, but from the relative inequality in taxation. ${ }^{152}$ Another factor in the Court's decision was that the assessment practice at issue was a unilateral application of West Virginia law by the local county tax assessor, which was contrary to the general expectation of equal taxation. ${ }^{153}$

However, since Allegheny, the Supreme Court has been reluctant to overturn tax classifications on equal protection grounds. In Nordlinger $v$. Hahn, the Court upheld a California constitutional amendment that greatly favored longtime owners over newer owners because the statute at issue promoted neighborhood stability and protected longtime owners' reliance interests in certain tax rates. ${ }^{154}$ The Supreme Court also upheld a state tax scheme that taxed riverboat slot machines at $20 \%$ while taxing racetrack slot machines at 36\% in Fitzgerald v. Racing Ass' $n$ of Central Iowa. ${ }^{155}$ The Supreme Court concluded that the promotion of riverboat

\footnotetext{
147. 488 U.S. 336, 339 (1989).

148. Id. at 338 .

149. Id. at 341

150. Id.

151. Id. at 345 ("[West Virginia's] Constitution and laws provide that all property of the kind held by petitioners shall be taxed at a rate uniform throughout the State according to its estimated market value.").

152. Id. at 346 .

153. Id. at 345 .

154. 505 U.S. $1,7,12,18$ (1992).

155. 539 U.S. 103, 105, 109 (2003), rev'd on state equal protection grounds, Racing Ass'n of Central Iowa v. Fitzgerald, 675 N.W.2d 1, 3 (Iowa 2004).
} 
and related businesses, as well as protection of their reliance interests, was a legitimate basis for the unequal tax treatment. ${ }^{156}$ The Court summarized its equal protection analysis by concluding "the facts do not preclud[e] an inference that the reason for the different tax rates was to help the riverboat industry or the river communities." 157

HB 2117 can be seen as unconstitutional on equal protection grounds under Allegheny, Nordlinger, and Fitzgerald. If a court were to interpret the holding of Allegheny as dependent on the West Virginia Constitution's presumption of tax equality, HB 2117 could be unconstitutional under equal protection because of the presumption of equality in Kansas income taxation outlined in Part III of this Comment. Because HB 2117 deviates from this constitutional presumption, its discriminatory structure could be particularly suspect under equal protection review.

There are also several important differences between HB 2117 and the taxation schemes in Nordlinger and Fitzgerald. As for Nordlinger, HB 2117 introduces new benefits, and consequently, does not harm business owners' reliance interests on previous tax rates (and obviously does not impact neighbored stability). As for Fitzgerald, the U.S. Supreme Court upheld the Iowa statute in Fitzgerald by identifying specific plausible benefits of the law. The Court concluded that the Iowa statute benefited a specific industry and a specific location. ${ }^{158}$ HB 2117 does not benefit one location, industry, or activity in particular. It benefits those who choose to use certain business forms. This encourages a legal classification, but does not rationally further any specific interest. Owners of Christian book stores and adult book stores alike may benefit equally under HB 2117. Liquor store owners and alcohol rehabilitation center owners may also benefit equally from the law. Also, the discriminatory tax treatment in Fitzgerald was a matter of degree. The racetrack slot machines were taxed at $36 \%$ while riverboat slot machines were taxed at 20\%. ${ }^{159}$ Under HB 2117, Kansas employees will be taxed at a rate approaching $4.9 \%$ while owners of the favored entities will not be taxed at all. ${ }^{160}$ This is obviously a larger relative difference between the favored and unflavored groups.

\footnotetext{
156. Id. at $108-09$.

157. Id. at 110 (alteration in original) (internal quotation marks and citation omitted).

158. Id. at 109 ("[T] he legislators may have wanted to encourage the economic development of river communities or to promote riverboat history, say, by providing incentives for riverboats to remain in the State, rather than relocate to other States.").

159. Id. at 105 .

160. KAN. LEGISLATIVE RESEARCH DEP'T, supra note 2.
} 


\section{HB 2117 and Kansas Tax Precedent}

The Kansas Supreme Court has also applied an equal protection-type analysis in the context of income tax disparities. The court has interpreted article 11, section 2 to require that "where a classification is made, that classification must be natural and not arbitrary or capricious, and all persons in the same class must be treated in the same way." " The court stated these requirements in Hartman v. State Commission of Revenue \& Taxation when it overturned a statute based on the unequal income tax treatment of two similar sources of income. ${ }^{162}$ The Kansas statute at issue (section 79-3216(a)) required "100 percent of the gain []be taken into account in computing net income" when a taxpayer received assets from a business liquidation. ${ }^{163}$ This imposed a much greater tax burden on taxpayers who received assets from a liquidated business compared to those who sold stock in a still-operating business. ${ }^{164}$ Those who sold stock in a still-operating business were only taxed on their net income from the sale. ${ }^{165}$ The Court found the distinction between these two types of sales unreasonable and concluded that

[B]oth classes were treated alike until the assertion of the percentage rate was applied, when a discrimination was made. In our opinion the result was not one having a reasonable relation to the subject of the right and privilege taxed, the classification made was not natural, and the members in the same class were not treated alike .... 166

This suggests not only a prohibition against "arbitrary" classifications, but a preference for classifications that have "a reasonable relation to the subject of the right and privilege taxed."167

The Kansas Supreme Court reaffirmed these implicit requirements of article 11, section 2 in Barker v. State when it upheld a statutory scheme that subjected federal military retirees to state income taxes while exempting state retirees. ${ }^{168}$ The Kansas Supreme Court concluded that

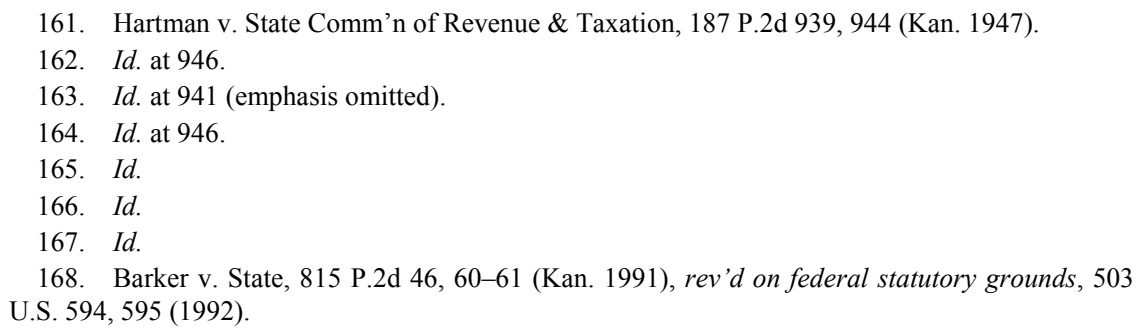


the state had a "rational reason" for the disparate treatment. ${ }^{169}$ The court's analysis indicated that the prohibition against "arbitrary" distinctions requires that a discriminatory tax "bear a reasonable relationship to the subject taxed." "Both Hartman and Barker make clear that Kansas income tax distinctions must related to the "subject" taxed.

The tax distinctions within HB 2117 fail this minimal standard. As previously explained, HB 2117 discriminates solely based on the source of the income. For example, an attorney working for a corporation is taxed under HB 2117, while an attorney working as a sole proprietor is not. ${ }^{171}$ If the "subject" of the Kansas income tax in both instances is professional services, what is the distinction between the corporate attorney and the independent attorney that is "rationally related" to providing these services? In Barker, the court reasoned that the state retirees deserved favorable tax treatment because it benefitted the state's interest in recruiting quality employees. ${ }^{172}$ In Hartman, the court concluded there was no legitimate distinction between the two types of asset sales. ${ }^{173}$ These holdings suggest that legal distinctions must be supported by substantive, nonlegal differences between the types of income. HB 2117 discriminates based on legal categories and not based on substantive distinctions, which renders it constitutionally vulnerable under the implicit requirements of article 11, section 2 of the Kansas Constitution.

\section{V. “ARBITRARY” ClASSIFICATIONS WITHIN HB 2117 AND UNCONSTITUTIONAL DELEGATION}

HB 2117 is also constitutionally vulnerable because of the specific tax mechanisms it uses to distinguish between types of income. One theme that runs through the article 11, section 2 cases in the previous section is the prohibition against "arbitrary or capricious" classifications. ${ }^{174}$ While the equal protection portion of this Comment addresses inequality between similar taxpayers, this Part examines the

\footnotetext{
169. Id. at 60 .

170. Id.

171. Dickinson et al., supra note 3, at 335 .

172. Barker, 815 P.2d at 60 (explaining that the "State has a rational reason for discriminating between state and federal retirees when it seeks to advance its interest in hiring and retaining qualified employees" (internal quotation marks omitted)).

173. Hartman v. State Comm'n of Revenue \& Taxation, 187 P.2d 939, 946 (Kan. 1947).

174. Id.; Barker, 815 P.2d at 60 .
} 
statutory mechanisms HB 2117 relies on to create that unequal treatment. HB 2117 creates substantive Kansas tax distinctions based on which federal form certain types of income are reported. ${ }^{175}$ This reliance on IRS forms establishes arbitrary distinctions within Kansas income tax law and is therefore likely unconstitutional. Similarly, because HB 2117 arbitrarily relies on IRS forms, it is constitutionally vulnerable as an impermissible delegation of Kansas legislative authority to a federal administrative agency. While the Kansas constitution explicitly allows for delegation by reference to federal tax "laws," delegation by reference to federal tax forms or instructions.

\section{A. IRS Forms Determine Substantive Kansas Tax Law Under HB 2117}

HB 2117 exempts sources and types of income based on which line the income is reported to the IRS. Specifically, HB 2117 exempts certain types of income by changing the way Kansas AGI is calculated for individuals under section 79-32,117 of the Kansas Statutes. ${ }^{177}$ After HB 2117, the statute defining AGI for Kansas purposes now reads:

(c) There shall be subtracted from federal adjusted gross income:

(xx) For all taxable years beginning after December 31, 2012, the amount of any: (1) Net profit from business as determined under the federal internal revenue code and reported from schedule $\mathrm{C}$ and on line 12 of the taxpayer's form 1040 federal individual income tax return; (2) net income from rental real estate, royalties, partnerships, $\mathrm{S}$ corporations, estates, trusts ... as determined under the federal internal revenue code and reported from schedule $\mathrm{E}$ and on line 17 of the taxpayer's form 1040 federal individual income tax return; and (3) net farm profit as determined under the federal internal revenue code and reported from schedule $\mathrm{F}$ and on line 18 of the taxpayer's form 1040 federal income tax return; all to the extent included in the taxpayer's federal adjusted gross income. For purposes of this subsection, references to the federal form 1040 and federal schedule $\mathrm{C}$, schedule $\mathrm{E}$, and schedule F, shall be to such form and schedules as they existed for

\footnotetext{
175. See Kan. Stat. AnN. § 79-32,117(c)(xx) (Supp. 2012).

176. KAN. CONST. art. XI, § 11.

177. Dickinson et al., supra note 3, at 300 (citing Sec. 40, 2012 Kan. Sess. Laws at 1088 (repealing KAN. STAT. ANN. § 79-32,117)).
} 
tax year 2011 and as revised thereafter by the internal revenue service. $^{178}$

The Kansas Department of Revenue has indicated that these references to the federal tax forms are not merely for reference, but instead, "determinative" as to whether an individual can exempt income. ${ }^{179}$

The Kansas Department of Revenue has provided three sets of requirements to qualify for each of the new exemptions in section 79$32,117(\mathrm{c})(\mathrm{xx}) .{ }^{180}$ These lists of requirements are written with explicit reference to the income being "properly reported" on certain lines of federal tax forms. ${ }^{181}$ For instance, to qualify for the net business profit exemption listed in paragraph $(\mathrm{xx})(1)$, the Department of Revenue says the income must be "properly reported on Schedule $\mathrm{C}$ of federal Form 1040 " and then included on "Line 12 of federal Form 1040."182 The Department states, "Income not properly reported in accordance with federal income tax law and instructions ... is outside the scope of ... (c) $(\mathrm{xx}) . " 183$ It is clear that compliance with federal tax forms is controlling for purposes of Kansas income tax law.

\section{B. HB 2117 Unconstitutionally Relies on Arbitrary Federal Tax Forms}

Several factors indicate that tying substantive Kansas tax law to individual lines on IRS forms is an "arbitrary" or "capricious" method of creating tax distinctions. Black's Law Dictionary defines "arbitrary" as "[d]epending on individual discretion ... determined by a judge rather than by fixed rules, procedures, or law." "184 Similarly, it defines "capricious" as "characterized by or guided by unpredictable or impulsive behavior." 185

Two factors indicate that HB 2117 imposes arbitrary distinctions by relying on IRS forms and instructions. First, the language in 26 U.S.C.

\footnotetext{
178. KAN. STAT. ANN. § 79-32,117(c)(xx).

179. See, e.g., Dickinson et al., supra note 3, at 302 ("The Department of Revenue takes the position that only income 'properly reported' on Schedule C qualifies for the paragraph ( $\mathrm{xx}$ ) subtraction. Therefore, Schedule $\mathrm{C}$ and the accompanying instructions are determinative." (citing Kan. Dep't of Revenue, Notice 12-11: Kansas Income Tax Changes to Addition and SubTRACTION MODIFICATIONS InCOME EXEMPT FROM KANSAS TAX 3 (2012), http://www.ksr evenue.org/taxnotices/notice12-11.pdf)).

180. KAN. DEP'T OF REVENUE, supra note 179, at 3-5.

181. Id.

182. Id. at 3 .

183. Id.

184. 119 (9th ed. 2009).

185. Id. at 239 .
} 
$\S 6011$ (a) indicates that IRS forms are dictated by discretionary federal administrative decisions. This section mandates that that every person required to file a tax return shall make one "according to the forms and regulations prescribed by the Secretary." 186 Second, the U.S. Supreme Court has stated that the major purpose of federal tax forms is to give the IRS sufficient tax information "with such uniformity, completeness, and arrangement" that processing the forms "may be readily accomplished." 187 Similarly, the U.S. Tax Court has previously stated that a filer's tax return could be sufficient (for statute of limitations purposes) despite not being completed on the correct forms. ${ }^{188}$ HB 2117 relies on federal tax forms not to streamline federal administrative convenience as contemplated by these courts, but instead to determine the content of Kansas tax law. Because HB 2117 uses the federal tax forms for a different purpose than the one contemplated by the federal government, it is more likely that taxpayers will be treated unfairly or arbitrarily.

The treatment of capital gains income from partnerships, $\mathrm{S}$ corporations, and LLCs is one specific example of how a particular federal tax form peculiarity will arbitrarily decide Kansas tax law. According to the post-HB 2117 version of section 79-32,117(xx)(2), income from partnerships, S corporations, and LLCs is exempt if it is properly reported "from schedule E and on line 17 of the taxpayer's form 1040 federal individual income tax return." ${ }^{189}$ The Department of Revenue has indicated that the instructions for Schedule K-1 (which is given to those receiving income from partnerships, S corporations., and LLCs) are determinative as to whether income is properly reported from Schedule E on line 17 of individual's Form 1040. ${ }^{190}$ Because the instructions accompanying Schedule K-1 say to report partnership, S corporation, and LLC capital gains income on Schedule D and not Schedule E, the Kansas Department of Revenue concludes that this type of income would not be properly reported on Line 17 of Form 1040 as the statute requires. ${ }^{191}$ Kansans will continue to pay income tax on capital gains from these entities for this reason.

\footnotetext{
186. I.R.C. § 6011(a) (2006).

187. Comm'r v. Lane-Wells Co., 321 U.S. 219, 223 (1944).

188. Beard v. Comm'r, 82 T.C. 766, 777 (1984), aff'd, 793 F.2d 139 (6th Cir. 1986).

189. KAN. STAT. ANN. § 79-32,117(c)(xx) (Supp. 2012).

190. Kan. Rev. Rule 19-2012-02, at 2, http://www.ksrevenue.org/taxnotices/RevRul19-201202.pdf.

191. See id. at $2-4$.
} 
This is an entirely arbitrary reliance on the federal form system. The most likely reason that capital gains from partnerships, $\mathrm{S}$ corporations, and LLCs are reported on Schedule D (and not Schedule E) before being reported on Form 1040 is that the federal government taxes long-term capital gains at a lower rate than other types of income. ${ }^{192}$ Schedule D is used to calculate how much of an individual's income is long-term versus short-term capital gains because of this deferential tax treatment. ${ }^{193}$ In effect, HB 2117 relies on federal tax forms to accomplish the exact opposite of what the IRS intended when it created this form structure. Partnership capital gains is not exempt from Kansas income taxation while ordinary partnership income will be reported on Schedule E, and it is therefore exempt from Kansas income taxation. This is ironic because HB 2117 relies on a federal form system which favors capital gains in order to create a system which disfavors capital gains. If, for example, Congress decides to tax long-term capital gains at the same rate as other types of income, capital gains from partnerships, $\mathrm{S}$ corporations, and LLCs would presumably not require Schedule D and would likely be reported on Schedule E (and thus on Line 17 of Form 1040 ) with the rest of partnership income. This would mean that capital gains from partnerships, S corporations, and LLCs would no longer be subject to Kansas income taxes because the federal government decided to raise taxes on capital gains.

Similarly, HB 2117 does not exempt gains from casualty or theft of business property or gains from sales, exchanges, and involuntary conversions of trade or business property because of federal technical considerations. ${ }^{194}$ The federal instructions for Schedule E specify that casualty or theft gains and losses must be reported on Form $4648 .{ }^{195}$ Consequently, these gains are not exempt from Kansas income taxation. HB 2117 also does not exempt income from sales, exchanges, and involuntary conversion of trade or business property because this type of income is reported on Form 4797 and therefore does not end up on

192. While neither the Schedule D itself nor the accompanying instructions explicitly state that the purposes of these forms is to calculate long-term capital gain income, the content of both these sources highly suggests as much. For instance, Schedule D includes two large boxes, one for shortterm capital gains, which are taxed at the ordinary rate, and one for long-term capital gains, which are taxed at a lower rate. See Internal Revenue Serv., Schedule D (Form 1040) (2012), http://www.irs.gov/pub/irs-pdf/f1040sd.pdf; INTERNAL REVENUE SERV., 2012 INSTRUCTIONS FOR SCHEDULE D, http://www.irs.gov/pub/irs-pdf/i1040sd.pdf; see also I.R.C. § 1(h) (2006).

193. INTERNAL REVENUE SERV., INSTRUCTIONS FOR SCHEDULE D, supra note 192.

194. See Dickinson et al., supra note 3, at 311 .

195. Id. (citing InTERNAL REVENUE SERV., 2011 InSTRUCTIONS FOR SCHEDUle E (Form 1040), SUPPLEMENTAL INCOME AND LOSS E-4 1 (2011), http://www.irs.gov/pub/irs-pdf/i1040se.pdf.) 
Schedule E and line 17 of the taxpayer's $1040 .{ }^{196}$ This is inconsistent with both the overall federal income tax scheme and the stated purpose of HB 2117. Under the federal system, generally, trade or business property held for more than one year is taxed at the capital gains rate. This system encourages investment in trade or business property because any profit from the sale, exchange, or involuntary conversion of that property is taxed at a lower rate than ordinary earned income. Under HB 2117, Kansas will tax this type of gain at a higher rate than distributed profits. For example, if a Kansas LLC decides to distribute $\$ 10,000$ of profits, the owners of the LLC will not be taxed by the state on that income. However, if that LLC decides buy a $\$ 10,000$ machine instead, and then sells that machine for a profit, Kansas will tax this income. Again, this is the opposite of what is contemplated by the federal tax system. HB 2117 uses a federal system that incentivizes investment to discourage investment in Kansas.

The HB 2117 scheme causes arbitrary treatment of Kansas taxpayers. While Kansas previously tied its income tax system to federal laws and definitions, ${ }^{197}$ these references more or less adopted the entirety of a federal tax system with Kansas-specific modifications. HB 2117 changes this by relying on individual federal provisions in ways not contemplated by the federal government. This creates the risk of inadvertent changes in Kansas tax law because of changes in the federal form structure. Consequently, this reliance on federal tax forms is an arbitrary basis for the differences in tax outcomes under HB 2117 and a violation of the implicit requirements of article 11, section 2 of the Kansas constitution.

\section{HB 2117 Unconstitutionally Delegates Kansas Legislative Authority to the IRS}

Related to HB 2117's reliance on "arbitrary" distinctions to tax similar taxpayers differently, is HB 2117's unconstitutional delegation of Kansas legislative authority to an administrative agency of the federal government.

Kansas precedent indicates that there are limited situations where the delegation of Kansas legislative power is appropriate. ${ }^{198}$ If the Kansas

\footnotetext{
196. Id. (citing Kan. Rev. Rul. 19-2012-02, at 4.)

197. Id. at 296 (noting Kansas's reliance on federal AGI as starting point for calculation of state AGI).

198. See State ex rel. Tomasic v. Unified Gov't, 955 P.2d 1136, 1147-48 (Kan. 1998) (“A legislature may try to delegate the legislative power to make a law. Such a delegation is improper,
} 
constitution does not allow for delegation of a particular power, then that delegation is a violation of the separation of powers doctrine embodied in article 11, section 1, "which vests legislative power with the legislature only." "199 The Kansas Supreme Court has defined legislative power as the "power to make a law, as opposed to the power to enforce a law," which is left to the administrative branch. ${ }^{200}$ The court has defined the difference between legislative and administrative power as a matter of specificity. ${ }^{201}$ If a statute contains "sufficient policies and standards to guide the nonlegislative body," then it is delegating administrative, rather than legislative, power. ${ }^{202}$

In the case of income tax delegation, the Kansas constitution specifically gives the legislature the ability to tie Kansas income tax law to federal law. Adopted in 1966, article 11, section 11 of the constitution reads:

In enacting any [income tax] law under section 2 of this article 11 , the legislature may ... define income by reference to or otherwise adopt by reference all or any part of the laws of the United States as they then exist, and, prospectively, as they may thereafter be amended or enacted, with such exceptions, additions or modifications as the legislature may determine ... 203

Specifically, section 79-32,109 of the Kansas Statutes adopts federal definitions by stating that "[a]ny term used in this act shall have the same meaning as when used in a comparable context" in the federal internal revenue code (IRC). ${ }^{204}$ During the 2013 session, the Kansas Legislature clarified that all references to federal forms, schedules or line numbers within the Kansas income tax act refer to such "form, schedule and line number as they existed for tax year 2011 and as revised thereafter by the internal revenue service." 205 While it is clear the legislature is allowed to adopt federal tax definitions within federal "laws," nothing suggests the legislature can delegate Kansas legislative authority based on federal tax forms and instructions.

\footnotetext{
unless specific constitutional authority allows the legislature to delegate its legislative power to a different branch of government.").

199. Id. at 1148 .

200. Id. at 1147 .

201. Id. at 1148 .

202. Id.

203. KAN. CONST. art. XI, § 11.

204. KAN. STAT. ANN. § 79-32,109 (Supp. 2012).

205. Act of April 16, 2013, ch. 87, 2013 Kan. Sess. Laws.
} 
There are important differences between federal tax laws and federal tax forms and instructions. The federal definition of adjusted gross income - on which current Kansas income tax law relies-is contained within a federal statute, ${ }^{206}$ meaning Congress engaged in a public process and passed a law to define adjusted gross income. Conversely, federal forms - on which HB 2117 relies - were created by internal processes within the U.S. Department of the Treasury and were "proscribed by the secretary.". ${ }^{207}$ As mentioned in the analysis above, an alteration in the federal form structure would change the content of Kansas tax law.

It appears that HB 2117's amendments to section 79-32,117 are the only instances in the entire Kansas income tax act which reference federal forms to create substantive Kansas tax distinctions. Section 793221 also references federal tax forms, but merely requires that Kansas tax returns "be made as nearly as practical in the same form as the corresponding form of the income tax return by the United States."208 Similarly, section 79-3222 requires that each individual or entity doing business in the state file a copy of her or its federal return with the Kansas director of taxation at or before the IRS deadline. ${ }^{209}$ However, all these references to federal forms are for the administrative convenience of the state and do not create substantive tax distinctions. In fact, there appear to be only four explicit references to federal regulations of any type (as opposed to federal statutes) within the Kansas income tax act. ${ }^{210}$ This novelty of relying on federal forms (or federal regulations of any kind) to create substantive tax distinctions within the Kansas income tax act suggests that there has previously been an assumption that the legislature could only adopt federal statutes as "laws" under article 11, section 11 of the Kansas Constitution. Because HB 2117 adopts federal

\footnotetext{
206. I.R.C. § 62 (2006 \& Supp. V 2011).

207. Id. $\S 6011$ (a) (2006).

208. KAN. STAT. ANN. § 79-3221(a).

209. Id. § 79-3222.

210. See id. § 79-32,175(a) (defining "Accessible to individuals with a disability" according to the federal statutory definition within 42 U.S.C. $§ 12101$ and " 28 CFR Part 36 and 29 CFR 1630 et seq."); id. § 79-32,211(a) (providing a tax credit for certain historic structure rehabilitation expenditures and adopting the federal definition of "placed in service" within I.R.C. § 47(b)(1) and 26 C.F.R. $\S 1.48-12(\mathrm{f})(2)$ for calculation of the Kansas credit); id. $\S 79-32,222$ (providing a tax credit for oil refinery expenditures "to comply with environmental standards ... pursuant to federal statute or regulation"); $i d$. $\S 79-324$ c(f) ("Nothing in this section shall be construed to allow disclosure ... where such disclosure is prohibited by the federal internal revenue code ... related federal internal revenue rules or regulations."). However, none of these references to federal regulations are similar to the use of IRS forms in section 79-32,117. The first two of these references adopt static federal regulatory definitions and the latter two references require compliance with overall federal "regulation" in a generic sense. Conversely, HB 2117 adopts individual lines on federal forms (as opposed to regulations) as determinative.
} 
tax forms and instructions, which are not statutory laws, it may constitute an unconstitutional delegation of Kansas legislative authority.

Missouri Pacific Railroad v. McDonald presented a similar tax delegation issue. ${ }^{211}$ In Missouri Pacific, a railroad challenged a Kansas statute that adopted the Interstate Commerce Commission's method of accounting, which produced an unfavorable result for the railroad compared to other businesses. ${ }^{212}$ The Kansas Supreme Court upheld this delegation and, notably, analyzed the issue without reference to article 11, section 11 of the Constitution, which was not yet enacted during the tax period at issue. ${ }^{213}$ There are three crucial differences between the use of the accounting system used in Missouri Pacific and HB 2117's use of individual federal tax forms and instructions.

First, the Kansas Supreme Court upheld the delegation in Missouri Pacific because the statute "provides for sufficient basic standards and reasonably definite policy for its administration." ${ }^{214}$ In effect, the Kansas Legislature was implementing a consistent, logical policy through its reliance on the federal accounting system. Conversely, HB 2117 adopts federal forms and implements accidental policy outcomes, at least in isolated instances. ${ }^{215}$

Second, the statute in Missouri Pacific adopted an entire federal system of railroad accounting. Although the plaintiff argued this system was primarily created for rate-making purposes, the court concluded that "rate-making is an integral part of the process wherein net income is ultimately derived." ${ }^{216}$ Here, HB 2117 adopts individual lines of federal tax forms as determinative regardless of how those lines fit with federal income tax law or Kansas income tax law. In fact, as in the case of HB 2117's treatment of capital gains, HB 2117 adopts federal forms in a manner specifically inconsistent with the federal government's use of those forms. This fact withdraws the tax distinctions within HB 2117 from coherence within the federal system.

Third, the court in Missouri Pacific noted that any Kansas tax determinations based on the federal commission's standards were "surrounded with safeguards." ${ }^{217}$ As the Kansas Department of Revenue

\footnotetext{
211. 486 P.2d 1347 (Kan. 1971).

212. Id. at $1348-51$.

213. Id. at $1348,1353$.

214. Id. at 1352 .

215. See supra notes $189-93$ and accompanying text.

216. Mo. Pac., 486 P.2d at 1352.

217. Id. at 1353 .
} 
has decided, decisions under HB 2117 will be determined exclusively by whether the income is "properly reported" on the federal forms. ${ }^{218}$ This means there are no Kansas specific safeguards in place to make sure that Kansas taxpayers are treated fairly or in a manner consistent with the Kansas legislature's chosen policy. Because HB 2117 creates substantive tax distinctions based on federal forms proscribed by the Secretary of the Treasury and not federal "laws" passed by Congress, it is an impermissible delegation of the Kansas Legislature's legislative authority.

\section{CONCLUSION}

HB 2117 is a revolutionary piece of legislation that dramatically changed Kansas income taxation. Largely because of the bill's unprecedented nature, HB 2117 is vulnerable on several constitutional fronts. HB 2117 enacts a regressive income tax scheme that may be impermissible under article 11, section 2 of the Kansas Constitution in light of the text and history of that provision. HB 2117 treats similar taxpayers differently and consequently may violate the state and federal constitutional guarantees of equal protection. Finally, HB 2117 creates arbitrary tax distinctions based on federal forms that are entirely devoid of substantive justifications. This potentially renders the statute an unconstitutional delegation of the Kansas Legislature's authority.

218. See, e.g., Dickinson et al., supra note 3, at 302. 